\title{
EVALUASI EFEK ERGOGENIK GINSENG
}

\author{
Oleh: Rachmah Laksmi Ambardini \\ Dosen IKORA FIK UNY
}

\begin{abstract}
Abstrak:
Ginseng merupakan tanaman obat yang sudah lama digunakan dan dipercaya mempunyai efek adaptogen dan ergogenik. Suplemen ginseng banyak dikonsumsi olahragawan dengan tujuan utama meningkatkan kinerja fisik. Salah satu spesies yang paling sering digunakan adalah Panax ginseng C.A.Meyer atau ginseng Korea. Komponen zat aktif Pginseng adalah ginsenoside. Berbagai penelitian menunjukkan bahwa Pginseng mampu meningkatkan kinerja fisik, meningkatkan fungsi psikologis, fungsi imun, dan anti diabetik.

Penelitian tentang efek ergogenik ginseng memberikan hasil yang bervariasi. Banyak penelitian bermakna jika dilakukan dengan menggunakan ekstrak ginseng standar, durasi penelitian lebih dari 8 minggu, dosis lebih dari $1 \mathrm{~g}$ akar kering atau ekuivalen, dan jumlah subjek yang lebih besar. Secara umum ginseng aman digunakan. Penelitian mendatang tentang efek ergogenik ginseng harus memperhatikan kualitas ekstrak, respons dosis, durasi penelitian, dan desain penelitian yang tepat.
\end{abstract}

Kata kunci: ginseng, efek ergogenik.

Ginseng sudah digunakan dalam pengobatan Cina sejak ribuan tahun sebagai stimulan, tonik, diuretik, dan untuk fungsi pencernaan. Di Eropa, fitofarmaka ginseng digunakan untuk meningkatkan kinerja fisik dan mental, menambah ketahanan terhadap stres, penyakit, dan mencegah kelelahan. Di Amerika, ginseng dikonsumsi lebih kurang 5-6 juta orang sebagai ergogenik alami. Di Indonesia, belum ada data yang jelas tentang penggunaan ginseng. Namun demikian, diduga 
penggunaan ginseng di kalangan olahragawan cukup banyak. Hal ini didukung oleh gencarnya promosi dari industri farmasi dan adanya kecenderungan masyarakat saat ini untuk menggunakan bahan-bahan alami, termasuk dalam meningkatkan ketahanan fisik dalam olahraga.

Olahragawan mengkonsumsi ginseng untuk meningkatkan kinerja endurance (misalnya lari, bersepeda, dayung, renang), menginduksi hipertrofi dan kekuatan otot (misalnya untuk binaraga, angkat berat, gulat), atau untuk meningkatkan kinerja pada berbagai peristiwa olahraga, baik olahraga prestasi maupun rekreasi. Efek ginseng dalam meningkatkan kinerja disebut efek ergogenik. Selain itu, ginseng mempunyai efek adaptogen, yang berarti membantu menormalkan fungsi tubuh yang berubah karena stres, baik stres fisik maupun mental. Olahragawan sering menggunakan adaptogen karena latihan fisik dianggap sebagai salah satu bentuk stres.

Efek farmakologi ginseng antara lain pada sistem kardiovaskular, sistem imun, sistem endokrin, cuan sistem saraf (Attele et al. 1999: 1685-93). Ginseng dipercaya dapat memperbaiki kinerja, khususnya selama kelelahan (fatigue). Beberapa temuan pada studi binatang menunjukkan bahwa ginseng menambah daya tahan terhadap stres fisik. Sejauh ini, penggunaan ginseng lebih berdasarkan bukti empiris. Walaupun demikian riset-riset terbaru menunjukkan efek anti kanker dan antioksidan ginseng (Gillis, 1997: 1-8), sedangkan penelitian tentang efek ergogenik ginseng masih memberikan hasil yang bervariasi.

Artikel ini akan membahas tentang profil tanaman ginseng, mekanisme aksi ginseng, efek ergogenik ginseng, dosis, dan efek samping ginseng.

\section{TANAMAN GINSENG.}

Selama dinasti Han, sudah ditulis tentang tanaman sheng, yang kemudian dikenal sebagai ginseng, yang artinya akar dari surga. Pada tahun 1883, genus ginseng 'Panax' ditambahkan. Panax berasal dari kata 'pan' yang berarti semua, dan 'axos' yang berarti menyembuhkan. Jadi Panax ginseng berarti akar dari surga yang meyembuhkan semua penyakit.

Istilah ginseng secara umum merujuk pada akar kering tanaman ginseng. Ginseng yang paling popular adalah Panax ginseng C.A. Meyer, yang dikenal juga sebagai ginseng Korea atau ginseng $C$ ina. Spesies ginseng lain yang juga termasuk dalam famili Araliacea adalah Panax japonicus (ginseng Jepang) dan Panax quinquefolius (ginseng Amerika). 
Panax ginseng C.A. Meyer diklasifikasikan oleh C.A.Meyer, seorang botanis. Tumbuhannya mempunyai tinggi $30-70 \mathrm{~cm}$, merupakan tumbuhan semak, akarnya mencapai kedalaman $20-30 \mathrm{~cm}$. Taksonomi Pginseng adalah sebagai berikut: kingdom plantae, subkingdom tracheobionta, divisi magnoliophyta, klas magnoliopsida, subklas rosidae, ordo apiales, famili araliaceae, genus panax, dan spesies Panax ginseng C.A. Meyer (Skinner,2000).

Ginseng bisa didapatkan dalam bentuk akar utuh, serbuk kering dari akar (ginseng putih), serbuk kering akar yang direbus (ginseng merah), larutan, dan ekstrak standar. Akar ginseng terdiri atas banyak komponen yaitu triterpene saponin; minyak esensial yang mengandung poliasetilen dan sequiterpenes; polisakarida; peptidoglikans; nitrogen, dan komponen lain seperti asam lemak, karbohidrat, dan fenol. Komponen yang dipercaya mempunyai banyak efek farmakologi adalah triterpene saponin, yang disebut ginsenoside (Sticher, 1998: 26-32).

Pembudidayaan dan pemrosesan ginseng berpengaruh terhadap zat aktif yang dikandungnya. Saat ini ada tuntutan untuk mengadakan standarisasi ekstrak ginseng, karena kelemahan fitofarmaka dibandingkan obat sintetik adalah variasi dalam kadar maupun jenis komponen zat aktifnya. Salah satu produk ginseng yang distandarisasi adalah Ginsana ${ }^{\circledR}$. Pembudidayaan dan pemrosesan dilakukan dengan prosedur baku sehingga diharapkan hasil ekstrak memenuhi standar yang sudah ditetapkan. Area pembudidayaan dilakukan di distrik Kae Song, Korea Selatan, bibit berasal dari biji terbaik dari tanaman ginseng berusia 5 tahun, temperatur tanah dijaga konstan dan terhindar dari sinar matahari langsung. Panen dilakukan setelah 4-6 tahun pada bulan September atau Oktober, saat kadar zat aktifnya optimum (Chinna, 1983: 1022-7). Akar yang akan diproses melewati -pemeriksaan mikrobiologis. Akar dibersihkan dari jamur atau bakteri, sedangkan pemrosesan ekstrak dilakukan pada temperatur rendah karena sifat zat aktif yang tidak tahan terhadap pemanasan tinggi. Standarisasi zat aktif menggunakan high performance liqiud chromatography (HPLC). Standarisasi ini untuk memastikan kandungan ginsenoside konsisten dan kadarnya mencapai efektivitas optimal. Ekstrak ginseng yang terstandarisasi mengandung 8 ginsenoside kunci, yaitu Rb1, Rb2, Rc, Rd, Re, Rf, Rg1, dan Rg2 (Chinna, 1983: 1022-7).

\section{MEKANISME AKSI}

Banyak pendapat mengenai mekanisme aksi ginseng. Zat aktif utama ginseng adalah ginsenoside dan mekanisme yang mendasari efek ginseng terutama karena 
adanya zat ini. Sebagian besar publikasi riset tentang aktivitas $P$. ginseng difokuskan pada ginsenoside. Mahady et al. (2000: 90-101) berpendapat bahwa ekstrak $P$. ginseng mempengaruhi aksis hipotalamus-hipofise-adrenal dan sistem imun. Studi lain yang menggunakan binatang dan in vitro mengindikasikan bahwa $P$. ginseng meningkatkan fagositosis, aktivitas sel natural killer (NK), produksi interferon, memperbaiki kinerja fisik dan mental pada mencit dan tikus, menyebabkan vasodilatasi, meningkatkan resitensi terhadap stres dari luar, dan mempunyai efek hipoglikemik.

Ada bukti tidak langsung dari percobaan pada binatang, yaitu bahwa peningkatan kinerja fisik dan mood setelah pemberian ginseng, berhubungan dengan perubahan neuroendokrin. Beberapa efek stimulan ginseng, seperti mengurangi kelelahan dan meningkatkan kinerja fisik, mungkin terkait dengan perubahan metabolisme karbohidrat dan peningkatan sintesis glikogen. Menurut Fan, et al. (1995), ginsenoside berperan pada stimulasi produksi nitrit oksida dalam sel sistem imun, sel endotelial vaskular, dan jaringan erektil.

Efek adaptogen maupun ergogenik ginseng berkaitan dengan kandungan ginsenoside ginseng. Ginsenoside mengubah mekanisme homeostasis penyediaan energi selama latihan fisik dengan cara meningkatkan kapasitas otot skelet dalam mengoksidasi asam lemak bebas menjadi glukosa untuk kepentingan produksi energi sel (WHO, 1999: 170-4).

\section{EFEK EK̄GOGENIK GINSENG}

Istilah ergogenik berarti suatu teknik latihan, peralatan mekanik, suplemen nutrisi, metode farmakologik, atau teknik psikologik yang dapat meningkatkan kinerja dalam latihan fisik dan atau meningkatkan adaptasi latihan (Leutholtz, 2001: 207-39). Menurut William (1998), ergogenic aid adalah suatu substansi, strategi, atau pengobatan yang secara teori didesain untuk meningkatkan kinerja fisik di atas efek latihan normal. Secara umum, ergogenik dipakai dengan tujuan meningkatkan kekuatan fisik atlet dan ketahanan mental. Ergogenik fisiologis umumnya berupa substansi farmakologi atau nutrisi, yang dipakai untuk meningkatkan kemampuan fisik dengan cara meningkatkan proses metabolik yang terlibat dalam produksi energi selama latihan fisik.

Peningkatan kinerja fisik dan mental diobservasi pada mencit dan tikus setelah pemberian ginseng scara oral maupun intraperitoneal. Pemberian secara oral fraksi saponin ginseng pada mencit dapat meningkatkan data tahan 
(endurance). Meskipun demikian, dua penelitian lain tidak menunjukkan hasil serupa (WHO, 1999).

Meskipun studi pada binatang memperlihatkan efek ergogenik ginseng, bukti-bukti efek ergogenik ginseng pada manusia masih lemah. Hal ini antara lain terkait dengan masalah metodologi seperti jumiah sampel yang tidak adekuat dan penelitian tidak menggunakan kontrol plasebo dan uji samar ganda (doubleblind). Pada kondisi yang tepat, ekstrak akar ginseng dapat meningkatkan kekuatan otot dan kapasitas kerja aerobik. Penelitian Forgo \& Kirchdorfer (1982) dengan subjek 20 orang, usia 18-31 tahun, 200 mg ekstrak ginseng standar selama 12 minggu menunjukkan perbaikan kapasitas aerobik, pengurangan produksi laktat, dan denyut nadi. Hasil penelitian Forgo \& Kirchdorfer (1983), dengan subjek 30 atlet elit usia 19-31 tahun, dosis ekstrak ginseng standar $200 \mathrm{mg}$ selama 9 minggu memberikan hasil yang bermakna untuk $\mathrm{VO}_{2} \max$, kapasitas vital, pengurangan produksi laktat dan denyut nadi, tetapi tidak bermakna untuk LH serum, testoteron, dan kortisol.

Beberapa penelitian tentang efek ergogenik ginseng tidak berhasil menunjukkan efek yang dimaksud (Bahrke \& Morgan, 2000: 113-33). Penelitian Engels et al. (1996) menggunakan $200 \mathrm{mg}$ P.ginseng G115 per hari pada wanita sehat dewasa muda, tidak menunjukkan perbedaan bermakna pada kinerja fisik, respons metabolik, dan $\mathrm{VO}_{2}$ max. Demikian juga dengan Engels et al.(1997) pada 31 pria sehat dengan dosis 200-400 mg P.ginseng G115 per hari selama 8 minggu, tidak ada perubahan bermakna pada respons fisiologi maupun psikologis pada latihan fisik submaksimal dan maksimal.

Penelitian efek ergogenik ginseng pada manusia memberikan hasil yang bervariasi. Penelitian yang berhasil menunjukkan efek ergogenik ginseng - umumnya menggunakan dosis yang lebih tinggi (dosis ekstrak standar yang mengandung ginsenoside setara dengan $2 \mathrm{~g}$ akar kering per hari), durasi penelitian lebih lama (lebih atau sama dengan 8 minggu), dan jumlah subjek yang lebih besar.

Ginseng memberikan hasil yang positif dalam memperbaiki waktu reaksi. Oleh karena itu, suplementasi ginseng dalam jangka panjang dengan ekstrak ginseng standar diperkirakan dapat menjaga atau meningkatkan kinerja pada olahraga yang membutuhkan reaksi dan pemikiran cepat. 


\section{DOSIS.}

Sebagian besar studi P.ginseng menggunakan dosis $200 \mathrm{mg}$ per hari. Sumber lain merekomendasikan 0,5 sampai 2 g akar kering per hari atau 100-300 mg ekstrak standar tiga kali sehari. Peneliti yang menguji efek ginseng terhadap kinerja fisik pada manusia menggunakan beberapa dosis yang berbeda. Salah satu produk ginseng yang popular adalah Ginsana ${ }^{@}$, yang mengandung $100 \mathrm{mg}$ ekstrak standar $P$. ginseng dengan kadar ginsenoside $4 \%$, ekuivalen dengan $500 \mathrm{mg}$ akar P.ginseng, dikonsumsi 2 kali sehari. Satu sumber menyebutkan, ginseng umumnya digunakan dalam jangka panjang dengan 2 minggu bebas ginseng setiap pemberian 2-3 minggu (Robbers et al., 1999: 211-20).

IOC tidak memasukkan ginseng dalam daftar substansi yang dilarang dengan pertimbangan belum cukup bukti yang menunjukkan efek ergogenik ginseng.

\section{EFEK SAMPING.}

Meskipun toksisitas oral ginseng pada mencit sudah diketahui, tetapi dosis toksik pada manusia belum diketahui. Belum ada laporan mengenai kasus toksisitas akut pada penggunaan ginseng dosis tinggi pada manusia. Ginseng relatif aman dan ditoleransi dengan baik oleh sebagian besar orang. Namun demikian, ginseng tidak dianjurkan diberikan pada anak-anak, penderita hipertensi, gangguan psikologis, nyeri kepala, palpitasi, insomnia, asma, infeksi dengan demam tinggi, dan kehamilan.

Efek samping yang pernah dilaporkan adalah hipertensi, euforia, kecemasan, insomnia, erupsi kulit, edema, dan diare setelah pemberian ginseng jangka panjang dengan dosis $3 \mathrm{~g}$ akar ginseng per hari.

\section{Kesimpulan.}

Suplemen P.ginseng dapat meningkatkan kinerja fisik dan mental jika dikonsumsi jangka panjang dan dosis yang cukup. Efek ergogenik ginseng tidak terlihat pada pemberian jangka pendek. Secara umum, suplemen ginseng aman, meskipun ada variabilitas individu.

Riset pada binatang dan in vitro sudah banyak dilakukan, tetapi studi pada manusia sebagai konsumen produk herbal, dalam hal ini ginseng masih 
terbatas. Penelitian mendatang tentang efek ergogenik ginseng sebaiknya diarahkan pada pengukuran kinerja fisik (waktu kelelahan, perubahan kekuatan untuk latihan ketahanan, perubahan komposisi tubuh, konsentrasi hormon, perubahan mood, dan perubahan neuromuskular). Studi-studi tersebut sebaiknya juga menguji kurva dosis-respon, yang umumnya masih belum dilakukan untuk sebagian besar suplemen herbal. Penggunaan ekstrak standar merupakan bahan terbaik untuk penelitian dan desain penelitian yang tepat diharapkan mampu menunjukkan efek ergogenik ginseng. 


\section{DAFTAR PUSTAKA}

Attele, J.D., Wua, J.A., \& Yuan, C.S. (1999) “Ginseng pharmacology, multiple constituens and multiple actions". Biochem Pharmacol (58): 1685-93.

Bahrke, M.S., \& Morgan, W.R. (2000) "Evaluation of the ergogenic properties of ginseng: an update”. Sport Med; 29: 113-33.

Chinna, C. (1983) "Panax ginseng- a survey". Oesterreichische Apotheker Zeitung, 37: 1022-7.

Engels, H.j., Said, J.M., \& Wirth,J.C. (1996): "Failure of chronic ginseng supplementation to affect work performance and energy metabolism in healthy adults females". Nutr Res,16: 1295-1305.

(1997) "No ergogenic effect of ginseng (Panax ginseng C.A.Meyer) during graded maximal aerobic exercise". J Am Diet Assoc, 97: 1110-5.

Fan, Z.H., Isobe, K., Kiuchi, K., \& Nakashima, I. (1995) "Enhancement of niytric oxide production from activated macrophages by a purificu' form of ginsenosides". Am J Chin Med. 23: 279-87.

Forgo, I. \& Kirchdorfer, A.M. (1982) "The effect of different ginsenoside concentration on physical work capacity”. Notabene Med;12: 721-7.

1983. Effects of drugs on physical performance and the hormonal system of athletes. MMW Munch Wochenschr,125:822-4.

Gillis, C.N. (1997) "Panax ginseng pharmacology: a nitric oxide link?” Biochem Pharmacol; 54 : $1-8$.

Leutholtz, A. (2001) Nutritional bealth. Totowa, NJ. Human Press Inc: 207-39.

Mahady, G.B., Gyllenhall, C., Fong, H.H., \& Farnsworth, N.R. (2000). “Ginsengs: a review of safety and efficacy". Nutr Clin Care; 3: 90-101.

Robbers, J.E., Tyler, V.E. (1999). Tyler's berbs of choice: the therapeutic use of phytomedicinals. New York, N.Y.: Haworth Herbal Press: 211-20.

Skinner, M.W. (2000) The plant database. National Plant Data Center, NRCS, USDA, USA.

Sticher, O. (1998) Getting to the root of ginseng. Chemtech 28 (4): 26-32.

William, M. (1998) “Nutritional ergogenic and sport performance”. Research Digest; 3(2): 1-3.

World Health Organization. (1999). WHO monograph on selected medicinal plant. Geneva: World Health Organization: 170-74. 